\title{
Studi Analisis Finansial Pendirian Industri Keripik Pisang di Provinsi Lampung
}

\section{Financial Feasibility Study of Banana Chips Agroindustry in Lampung Province}

\author{
Sri Hidayati ${ }^{1 *}$, Neti Yuliana ${ }^{2}$, Tanto Pratondo Utomo ${ }^{3}$, Rio Cakradinata ${ }^{4}$ \\ ${ }^{1,2,3}$ University of Lampung/ Agricultural Technology \\ ${ }^{4}$ University of Lampung/ Agricultural Industry Technology \\ *E-mail : srihidayati.unila@gmail.com
}

\begin{abstract}
This study aims to determine the analysis of the location of the establishment of a suitable banana chips industry in Lampung by using an exponential comparison method and the feasibility of financial analysis.. The research method uses observation, survey and interview techniques. To determine the location of the plant using the Exponential Comparison Method. The results showed that the suitable location was Ketapang subdistrict in south Lampung regency with a value of 11129 and was declared financially feasible because it had a positive Net Present Value (NPV), the value of the Internal Rate of Return (IRR) was greater than the prevailing interest rate at present, the value of the Benefit/Cost $(B / C)$ ratio is more than 1 and the payback period year 11 months is the maximum business feasibility at a $15 \%$ increase in raw materials per year.
\end{abstract}

Keywords: Agroindustry, Banana Chips, Feasibility

Disubmit: 16 Januari 2020 ; Diterima: 16 Februari 2020; Disetujui: 25 Februari 2020

\section{PENDAHULUAN}

Provinsi Lampung merupakan produsen pisang terbesar di Indonesia yaitu 1.937 .349 ton atau 26,54 \% dari total produksi pisang nasional (BPS, 2017). Pemanfaatan buah pisang yang sebagian besar masih dikonsumsi dalam bentuk segar. Faktor yang mempengaruhi produktivitas pisang di lampung yaitu harga jual, hama penyakit tanaman, akses pasar dan varietas pisang (Apriyani. et al, 2019). Pisang merupakan bahan pangan yang mengandung antioksidan (Babu et al, 2012) dan sumber antimikroba alami (Chandra et al., 2010; Okorondu et a.l, 2010; dan Sumathy et al., 2011). Kulit pisang juga maemiliki kandungan tinggi antioksidan dan bersifat anti bakteri ((Nagarajaiah \& Prakash, 2011; Ningsih et al., 2013)).

Yuliana et al. (2019) melaporkan bahwa industri pengolahan pisang berdasarkan analisis nilai tambah adalah Rp3,281/kg. Untuk mengetahui kelayakan suatu usaha diperlukan analisis kelayakan industri atau disebut juga feasibility study yaitu suatu kegiatan untuk menilai sejauh mana manfaat yang dapat diperoleh dalam melaksanakan suatu kegiatan usaha dimana hasilnya digunakan untuk mempertimbangkan apakah gagasan diterima atau ditolak atau merupakan suatu gambaran kegiatan usaha yang direncanakan, sesuai dengan kondisi, potensi, serta peluang yang tersedia dari berbagai aspek (Ibrahim, 2009). Hasil penelitian Setiawati, (2017) menyatakan peluang yang berpengaruh pada pengembangan agroindustri keripik pisang di Desa Hegarmanah Kecamatan Cidolog Kabupaten Ciamis adalah tidak ada pesaing produk sejenis disatu 
daerah, pangsa pasar yang masih luas, permintaan semakin meningkat tetapi cuaca tidak mempengaruhi produksi. Faktor-faktor yang menjadi ancaman yaitu kelangkaan bahan baku, fluktuasi harga bahan baku, kurang adanya peran dari pemerintah, dan kenaikan harga sarana produksi sehingga untuk melakukan kelayakan agroindustri perlu dilakukan analisis kelayakan bisnis.

Pendirian agroindustri keripik pisang diharapkan dapat menjadi solusi. Pengolahan menjadi keripik pisang sebagai potensi olahan yang memiliki nilai tambah bagi masyarakat (Direktorat Jenderal Pengolahan dan Pemasaran hasil Pertanian, 2015). Penentuan agroindustri keripik pisang dapat dilakukan melalui pendekatan sumber bahan baku pisang yang potensial di Provinsi Lampung. Penelitian ini dilakukan dengan tujuan untuk mengetahui kelayakan pendirian agroindustri keripik pisang di Provinsi Lampung ditinjau dari aspek pasar dan pemasaran, aspek teknis dan teknologi serta aspek finansial dan analisis pemilihan lokasi berdasarkan metode perbandingan eksponensial.

\section{METODE PENELITIAN}

Metode penelitian yang digunakan adalah metode studi pustaka, observasi, survey, dan juga wawancara dengan para pakar yang berkaitan dengan masalah pendirian agroindustri berbasis pisang. Pengumpulan data meliputi data primer dan sekunder dengan tujuan untuk rnemperoleh informasi, gambaran, dan keterangan sehingga data tersebut diharapkan dapat dipergunakan untuk pemecahan masalah dan pertimbangan pengambilan keputusan. Data yang sudah diperoleh kemudian diolah menggunakan Metode Perbandingan Eksponensial (MPE) untuk menentukan lokasi pabrik, Analisis finansial dilakukan dengan menghitung net present value, internal rate of return, benefit cost ratio, payback period, dan analisis sensitivitas (Nurainy, 2017).

Net Present Value (NPV). Nilai bersih sekarang (Net Present Value / NPV) merupakan metode yang menghitung selisih antara manfaat / penerimaan dengan biaya / pengeluaran. (Gray et al., 2017); Padangaran, 2008). Nilai NPV menggunakan perhitungan (Mariyah, 2010):

$\mathrm{NPV}=\sum_{\mathrm{t}=1}^{\mathrm{n}} \frac{\mathrm{B}_{\mathrm{t}}-\mathrm{C}_{\mathrm{t}}}{(1+\mathrm{i})^{\mathrm{t}}}$

\section{Keterangan:}

$\mathrm{B}_{\mathrm{t}} \quad=$ keuntungan pada tehun ke- $\mathrm{t}$

$\mathrm{C}_{\mathrm{t}}$ = biaya pada tahun ke- $\mathrm{t}$

$\mathrm{N}$ = umur ekonomis dari proyek

$\mathrm{i} \quad=$ suku bunga yang berlaku

Jika NPV $\geq 0$ maka proyek dapat dijalankan, nika NPV $<0$ maka proyek ditolak.

Internal Rate of Return (IRR). IRR adalah suku bunga nilai sekarang (present value of future proceed) dengan jumlah nilai sekarang dari pengeluaran untuk investasi. IRR adalah nilai faktor diskonto (i) yang membuat NPV dari proyek sama dengan nol (Mariyah, 2010) yaitu :

$$
I R R=i_{1}+\frac{N P V_{1}}{\left(N P V_{1}-N P V_{2}\right)}\left(i_{2}-i_{1}\right)
$$


Keterangan:

$\mathrm{NPV}_{(+)}=\mathrm{NPV}$ bernilai positif

$\mathrm{NPV}_{(-)}=\mathrm{NPV}$ bernilai negatif

$\mathrm{i}_{(+)} \quad=$ suku bunga yang membuat NPV positif

$\mathrm{i}_{(-)} \quad$ = suku bunga yang membuat NPV negatif

Jika IRR dari suatu proyek sama dengan tingkat suku bunga yang berlaku, maka NPV dari proyek itu sebesar 0. Jika IRR $\geq i$, maka proyek layak untuk dijalankan, begitupun sebaliknya.

Net Benefit-Cost Ratio (net B/C). Net B/C adalah rasio antara jumlah present value Bt-Ct yang positif dengan jumlah present value Bt- Ct yang negatif dengan persamaan sebagai berikut (Mariyah, 2010):

$$
N \quad B / C=\frac{\sum_{t-1}^{n} \frac{B_{t}-C_{t}}{(1+i)^{t}}}{\sum_{t-1}^{n} \frac{C_{t}-B_{t}}{(1+i)^{t}}}
$$

Keterangan:

$\mathrm{B}=$ Penerimaan total

$\mathrm{C}$ = biaya total

$\mathrm{i} \quad=$ tingkat suku bunga

$\mathrm{n} \quad=$ umur ekonomis dalam tahun

$\mathrm{t} \quad=1,2, \ldots, \mathrm{n}$.

Suatu usaha dinyatakan layak secara finansial jika nilai net B/C lebih tinggi daripada 1 .

Pay Back Periode (PBP). Pay back periode (PBP) merupakan periode dari waktu yang dibutuhkan untuk mencapai profit suatu investasi yang nilainya sama dengan jumlah biaya yang dikeluarkan pada investasi tersebut (Newman, 1990). Analisa titik pulang pokok dengan rumus (Harlistaria et al., 2012) :

$P=\frac{l}{O}$

Dimana:

$\mathrm{P} \quad=$ Waktu yang diperlukan untuk mencapai titik pulang pokok.

I = Penanaman modal awal (investasi).

OC $=$ Penerimaan tiap tahun.

Penentuan Lokasi Industri. Penentuan lokasi dilakukan dengan menggunakan Metode Perbandingan Eksponensial (MPE). Metode Perbandingan Exponensial (MPE) adalah salah satu metode dari Decision Suport System (DSS) yang digunakan untuk menentukan urutan prioritas alternatif keputusan dengan kriteria jamak (Marimin \& Maghfiroh, 2011).

$$
\text { Total nilai }\left(\mathrm{TN}_{\mathrm{i}}\right)=\sum_{\mathrm{j}=1}^{\mathrm{m}}\left(\mathrm{RK}_{\mathrm{ii}}\right)^{\mathrm{TKK} \mathrm{j}}
$$

Keterangan :

$\mathrm{TNi}=$ Total nilai alternatif $\mathrm{ke}-\mathrm{i}$

RK ij = derajat kepentingan relatif kriteria ke-j pada pilihan keputusan $\mathrm{i}$ 
TKK $\mathrm{j}=$ derajat kepentingan kritera keputusan ke-j; TKKj > 0; bulat

$\mathrm{n} \quad=$ jumlah pilihan keputusan

$\mathrm{m} \quad=$ jumlah kriteria keputusan

\section{HASIL DAN PEMBAHASAN}

Aspek Pasar dan Pemasaran. Masyarakat Indonesia secara umum sudah mengenal buah pisang dan produk olahannya. Salah satu produk olahan yang sangat dikenal adalah keripik pisang. Berdasarkan wawancara dengan salah satu industri keripik pisang di Bandar lampung, realisasi penjualan terjadi kenaikan per bulannya sebesar 17090 kg keripik yang senilai dengan Rp. 939.950.000,- Permintaan pasar akan keripik pisang yang semakin meningkat menunjukkan adanya peluang pasar yang menjanjikan sebagai komoditas produk makanan ringan. Konsumen nasional yang umumnya dari pulau Jawa dan sekitarnya pun dalam membeli keripik pisang belum dapat dipenuhi oleh industri yang ada saat ini, sehingga sering terjadi para konsumen kesulitan mendapatkan keripik pisang seperti yang diharapkan. Hal ini memungkinkan bahwa bisnis pembuatan keripik pisang masih dapat dilakukan tanpa merusak keseimbangan pasar yang ada. Hasil penelitian Predita dan Budiani (2012). beberapa wilayah seperti jakarta, palembang, daerah jawa seperti Yogyakarta merupakan proses pemasaran yang akan dikembangkan oleh pengusaha keripik Lampung.

Pesaing Usaha. Persaingan dalam dunia bisnis industri keripik pisang sangat ketat. Hal ini mengacu pada banyaknya produk-produk keripik pisang yang ada di pasaran. Namun sebagian besar keripik pisang ini diolah dalam skala kecil dalam bentuk industri rumah tangga atau UKM dan masih sedikit dalam industri skala besar. Pesaing usaha agroindusti keripik pisang ini di Provinsi Lampung contohnya adalah di Kawasan Sentra Industri Keripik yang terletak di Jalan Pagar Alam Bandar Lampung. Beberapa pesaing usaha keripik selain di Bandar Lampung juga terdapat sentra keripik seperti didaerah Segala Mider yaitu sebagian besar usaha di sentra keripik (47\%) menghasilkan keripik antara 12 s.d. $199 \mathrm{~kg}$ per minggu, 44\% menghasilkan keripik antara 200 s.d. $414 \mathrm{~kg}$ per minggu, dan hanya 9\% atau 3 unit usaha saja yang menghasilkan keripik antara 415 s.d. $3.036 \mathrm{~kg}$ per minggu (Ardansyah dan Tjioener, 2012).

Penentuan Lokasi Pendirian Agroindustri. Penentuan lokasi dilakukan melihat 5 kabupaten potensi penghasil pisang terbesar di Lampung yaitu: Kabupaten Lampung Selatan, Pesawaran, Lampung Tengah, Tanggamus dan Lampung Timur. Maulana (2018) menyatakan beberapa faktor yang mempengaruhi pemilihan lokasi suatu industri adalah: ketersediaan tenaga kerja, listrik, keamanan, faktor angkutan, peran pemerintah, sikap masyarakat, harga tanah dan bangunan serta kemungkinan perluasan. Oktiananda \& Nazamuddin, 2016) menyatakan bahwa berjalannya suatu usaha industri rumah tangga dikarenakan pentingnya faktor lokasi, bahan baku dan fasilitas seperti lahan pribadi dan infrastruktur yang memadai dan dari segi kelayakan. Menurut Candy \& Pamungkas (2013), faktor yang mempengaruhi pemilihan lokasi industry adalah ketersediaan bahan baku, fasilitas penunjang, infrastruktur, ketersediaan tenaga kerja, kondisi lokasi, pemasaran dan rencana tata ruang. Hasil analisis menggunakan Metode Perbandingan Eksponensial (MPE), kabupaten terpilih adalah Lampung Selatan dengan nilai MPE sebesar 4921. Salah satu faktor penentu adalah ketersediaan bahan baku dan kemudahan mendapatkan tenaga kerja. Selain itu adanya sarana tansportasi seperti akses jalan tol, Pelabuhan Bakauheni, Bandar Udara Raden Inten II dan juga infrastuktur jalan yang akan dilintasi jalan tol sumatera. Sarana air bersih di Lampung Selatan disediakan oleh PDAM Tirta Jasa dan adanya kemudahan akses pasar karena Lampung selatan merupakan gerbang menuju pulau jawa yang merupakan pangsa pasar utama. Analisi MPE berikutnya adalah memilih kecamatan untuk menentukan lokasi terbaik di kabupaten Lampung selatan (Tabel 1). 
Tabel 1. Penentuan Lokasi Pabrik dengan Metode MPE

\begin{tabular}{|c|c|c|c|c|c|c|c|}
\hline \multirow{3}{*}{ Kriteria } & \multicolumn{6}{|c|}{ Alternatif Lokasi Kecamatan } & \multirow{3}{*}{ Bobot } \\
\hline & \multicolumn{2}{|c|}{ Ketapang } & \multicolumn{2}{|c|}{ Kalianda } & \multicolumn{2}{|c|}{ Rajabasa } & \\
\hline & Poin & Nilai & Poin & Nilai & Poin & Nilai & \\
\hline $\begin{array}{l}\text { Tingkat kemudahan } \\
\text { perizinan pendirian } \\
\text { industri }\end{array}$ & 4 & 1024 & 4 & 1024 & 4 & 1024 & 5 \\
\hline $\begin{array}{l}\text { Dukungan } \\
\text { pemerintah } \\
\text { terhadap } \\
\text { pengembangan } \\
\text { industri }\end{array}$ & 5 & 3125 & 4 & 1024 & 4 & 1024 & 5 \\
\hline $\begin{array}{l}\text { Tingkat pajak bumi } \\
\text { dan bangunan }\end{array}$ & 4 & 256 & 4 & 256 & 4 & 256 & 4 \\
\hline $\begin{array}{l}\text { Kondisi daerah } \\
\text { yang kondusif }\end{array}$ & 4 & 1024 & 4 & 1024 & 4 & 1024 & 5 \\
\hline $\begin{array}{l}\text { Ketersediaan } \\
\text { Sarana transportasi }\end{array}$ & 4 & 256 & 4 & 256 & 3 & 81 & 4 \\
\hline $\begin{array}{l}\text { Ketersediaan sarana } \\
\text { listrik }\end{array}$ & 4 & 1024 & 4 & 1024 & 4 & 1024 & 5 \\
\hline $\begin{array}{l}\text { Dukungan } \\
\text { masyarakat di } \\
\text { sekitar lokasi } \\
\text { pendirian }\end{array}$ & 4 & 256 & 4 & 256 & 4 & 256 & 4 \\
\hline $\begin{array}{l}\text { Tingkat adaptasi } \\
\text { masyarakat } \\
\text { terhadap industri }\end{array}$ & 4 & 256 & 4 & 256 & 4 & 256 & 4 \\
\hline $\begin{array}{l}\text { Ketersediaan sarana } \\
\text { telekomunikasi }\end{array}$ & 4 & 256 & 4 & 256 & 4 & 256 & 4 \\
\hline $\begin{array}{l}\text { Ketersediaan sarana } \\
\text { air }\end{array}$ & 3 & 81 & 3 & 81 & 4 & 256 & 4 \\
\hline Potensi bahan baku & 4 & 1024 & 4 & 1024 & 4 & 1024 & 5 \\
\hline $\begin{array}{l}\text { Ketersediaan tenaga } \\
\text { kerja }\end{array}$ & 4 & 256 & 4 & 256 & 4 & 256 & 4 \\
\hline $\begin{array}{l}\text { Ketersediaan lahan } \\
\text { untuk industri }\end{array}$ & 4 & 1024 & 3 & 243 & 3 & 243 & 5 \\
\hline $\begin{array}{l}\text { Pasokan bahan } \\
\text { baku }\end{array}$ & 4 & 1024 & 4 & 1024 & 4 & 1024 & 5 \\
\hline Aksesibilitas pasar & 3 & 243 & 4 & 1024 & 4 & 1024 & 5 \\
\hline Total & & 11129 & & 9028 & & 9028 & \\
\hline
\end{tabular}

Analisis MPE menunjukkan bahwa Kecamatan Ketapang memiliki nilai MPE tertinggi yaitu sebesar 11129. Luas wilayah mencapai $186,60 \mathrm{~km}^{2}$ atau 9,33\% dari total luas Kabupaten Lampung Selatan, terdiri dari 17 desa yang sebagian besar wilayah berupa dataran yang merupakan areal pertanian dan perkebunan ([BPS]. Badan Pusat Statistik Lampung Selatan, 2016), dengan kepadatan penduduk di Ketapang adalah $260 \mathrm{jiwa} / \mathrm{km}^{2}$. Sektor unggulan adalah tanaman pisang yang produksinya mencapai 254 ribu ton pada Tahun 2013 dan sebagian besar dijual ke luar daerah (Tabel 2). 
Tabel 2. Produksi Pisang menurut Kecamatan di Kabupaten Lampung Selatan

\begin{tabular}{clcc}
\hline \multirow{2}{*}{ No Kecamatan } & & \multicolumn{2}{c}{ Pisang (Ton) } \\
\cline { 3 - 4 } & & 2014 & 2015 \\
\hline 1 & Natar & $2.830,0$ & $3.220,0$ \\
2 & Jati Agung & $4.990,0$ & $4.250,0$ \\
3 & Tanjung Bintang & $8.050,0$ & $8.050,0$ \\
4 & Tanjung Sari & $5.260,0$ & $6.630,0$ \\
5 & Katibung & $1.421,0$ & $2.656,6$ \\
6 & Merbau Mataram & $12.017,9$ & $10.280,4$ \\
7 & Way Sulan & 915,1 & $1.569,1$ \\
8 & Sidomulyo & $32.566,0$ & $26.426,0$ \\
9 & Candipuro & $3.980,0$ & $3.610,0$ \\
10 & Way Panji & $3.236,3$ & $2.282,2$ \\
11 & Kalianda & $67.644,4$ & $64.041,6$ \\
12 & Rajabasa & $50.723,1$ & $52.081,1$ \\
13 & Palas & $19.400,0$ & $23.750,0$ \\
14 & Sragi & $5.565,0$ & $8.048,5$ \\
15 & Penengahan & $19.400,0$ & $42.200,0$ \\
16 & Ketapang & $172.200,0$ & $132.000,0$ \\
17 & Bakauheni & $17.040,0$ & $35.600,0$ \\
\hline & & $427.239,0$ & $426.695,50$ \\
\hline
\end{tabular}

Sumber : Badan Pusat Statistik Lampung Selatan, 2016

Bahan Baku. Bahan baku pembuatan keripik pisang terdiri dari bahan baku utama, bahan baku penolong serta bahan baku tambahan. Bahan baku utama yang dapat digunakan untuk pembuatan keripik pisang adalah Pisang Kepok, Tanduk, Nangka, Kapas ataupun Siam, dan pisang olahan lainnya (Prabawati $e t$ al, 2008). Menurut Direktorat Pengolahan Hasil Pertanian (2009) bahan baku penolong dalam pembuatan keripik pisang antara lain air bersih, minyak goreng, dan larutan natrium bisulfit $\left(\mathrm{Na}_{2} \mathrm{SO}_{3}\right)$. Sedangkan untuk bahan baku tambahan pembuatan keripik pisang yang diperlukan sebagai penambah rasa, antara lain: garam halus untuk rasa asin; gula pasir, gula merah, dan gula semut untuk rasa manis; cabai bubuk untuk rasa pedas; dan bumbu untuk keripik dengan rasa khas (Prabawati et al, 2008)

Kapasitas Produksi. Produksi pisang Kabupaten Lampung Selatan tahun 2015 (Tabel 3) menjadi acuan dalam penentuan kapasitas produksi keripik pisang yaitu sebesar 426.695,5 ton/tahun atau 426.695.500 kg/tahun. Produksi keripik pisang direncanakan menggunakan bahan baku sebesar $1 \%$ atau 4.266.955 kg/tahun dari total produksi pisang Kabupaten Lampung Selatan tersebut (Tabel 3, Gambar 1). Produksi pisang mengalami kenaikan tiap tahun sehingga ketersediaan bahan baku pisamg akan tetap terpenuhi.

Proses Produksi. Menurut Direktorat Pengolahan Hasil Pertanian (2009) produksi keripik pisang meliputi beberapa prosedur, antara lain: penyiapan bahan baku, sortasi, pengupasan dan pengirisan, perendaman, penggorengan, pendinginan, sortasi, pengemasan dan pelabelan, serta penyimpanan.

Kebutuhan Ruang dan Tata Letak Pabrik. Kebutuhan ruang adalah kebutuhan terhadap luasan tertentu yang diperlukan para pekerja untuk bergerak.Kebutuhan terhadap luas ruangan pada industri keripik pisang ini sebesar 212,04 $\mathrm{m}^{2}$. Pembagian ruangan berjumlah 15 ruang yang terdiri dari ruang penerimaan bahan baku, ruang penyimpanan bahan baku, ruang pengirisan, ruang perendaman dan penirisan, ruang pengorengan, ruang pencampuran bumbu (seasoning), ruang pengemasan dan pelabelan, ruang Hal 85 Volume 20 Nomor 1, 2020 
Hidayati Sri, dkk : Studi Analisis Finansial Pendirian Industri Keripik Pisang di Provinsi Lampung.........

penyimpanan, kantor, laboratorium, IPAL, ruang generator, pos keamanan dan area halaman parkir, mushola, toilet, kantin, klinik.

Tabel 3. Produksi pisang di Kabupaten Lampung Selatan Tahun 2011 - 2016.

\begin{tabular}{ccccccc}
\hline \multirow{2}{*}{ Pisang } & \multicolumn{6}{c}{ Tahun } \\
\cline { 2 - 7 } & 2011 & 2012 & 2013 & 2014 & 2015 & 2016 \\
\hline Ton & $199.378,80$ & $199.415,60$ & $211.803,70$ & $427.239,00$ & $426.695,50$ & $433.458,00$ \\
\hline Sumber: & $\begin{array}{l}\text { Dinas Pertanian Tanaman Pangan dan Hortikultura Provinsi Lampung (2015), } \\
\text { BPS Lampung Selatan (2016) dan BPS Provinsi Lampung (2017). }\end{array}$
\end{tabular}

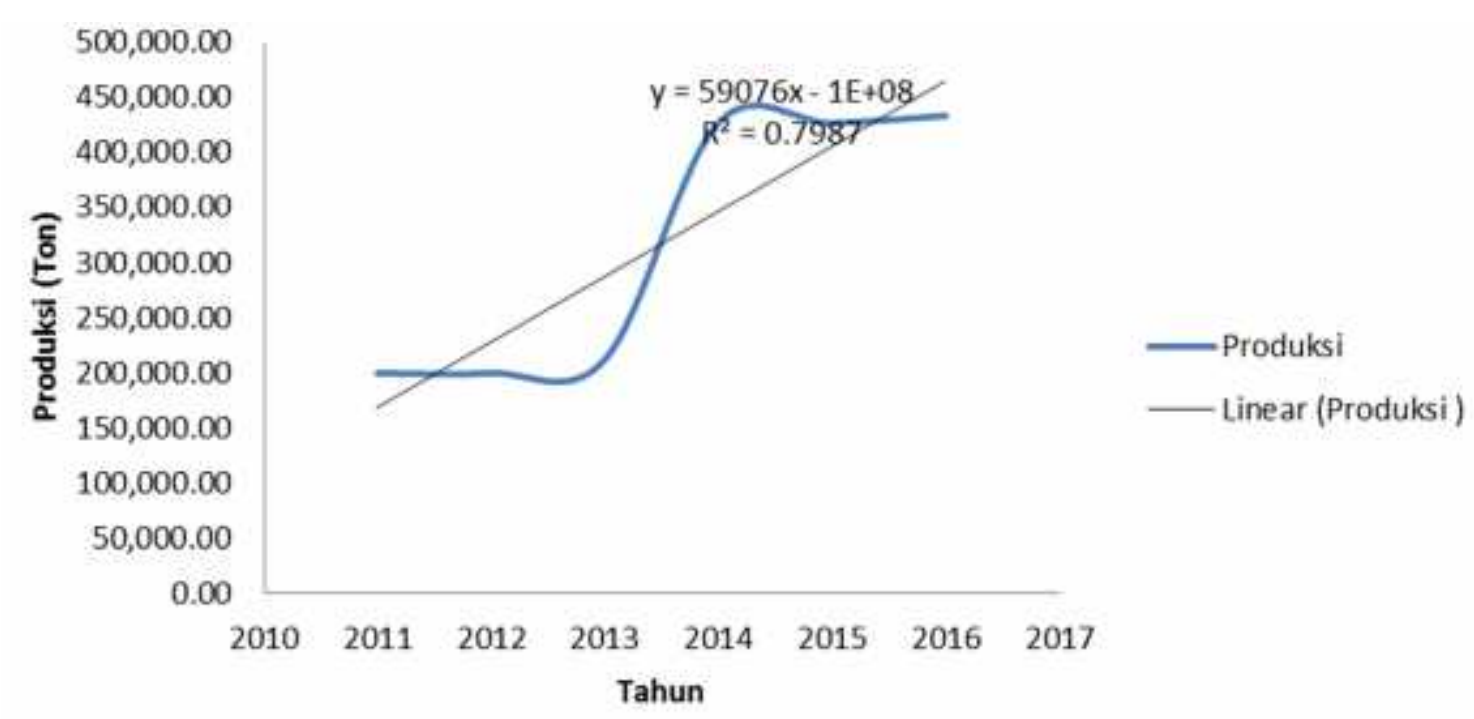

Gambar 1. Trend kenaikan produksi pisang di kabupaten lampung Selatan

Analisis Kelayakan Finansial. Analisis finansial dilakukan dengan tujuan untuk menentukan rencana investasi melalui perhitungan biaya dan manfaat yang diharapkan dengan membandingkan antara pengeluaran dan pendapatan melalui asumsi perhitungan. Perhitungan kelayakan usaha dilakukan melalui kriteria-kriteria, antara lain: Net Present Value (NPV), Internal Rate of Return (IRR), Net Benefit Ratio (Net B/C), dan Pay Back Periode (PBP) (Ibrahim, 2009) (Tabel 4).

Tabel 4.Kriteria kelayakan investasi agroindustri keripik pisang

Kriteria Investasi

\section{BANK KONVENSIONAL}

KAPASITAS 1.308,9 (ton/tahun)

\begin{tabular}{lrl}
\hline NPV (Rp.) & 38.418 .770 .971 & Layak \\
IRR (\%) & $46,43 \%$ & Layak \\
Net B/C & 5,27 & Layak \\
PBP (tahun) & 1,90 & Layak \\
\hline
\end{tabular}

Berdasarkan Tabel 4, hasil dari perhitungan NPV untuk pendanaan dari bank konvensional sebesar Rp. 38.418.770.971,-. Nilai pendanaan yang didapat lebih besar daripada nol, oleh karena itu maka industri keripik pisang dinyatakan layak sesuai perhitungan NPV. Sedangkan hasil dari perhitungan IRR sebesar $46,43 \%$, lebih besar dibandingkan factor diskonto yang digunakan yaitu $12,5 \%$, artinya investasi tersebut 
memberikan manfaat lebih dibandingkan dengan suku bunga yang diberikan oleh bank, maka dapat dikatakan industri keripik pisang layak untuk direalisasikan. Hasil dari perhitungan Net Benefit Ratio (Net $B / C$ ) atau PI untuk pendanaan dari bank konvensional adalah sebesar 5,27. Nilai tersebut menerangkan bahwa industri keripik pisang layak untuk direalisasikan, karena mempunyai nilai PI lebih besar dari satu. Hasil perhitungan periode pengembalian (Pay Back Periode) untuk skema kredit dari bank konvensional sebesar 1,90. Nilai tersebut menerangkan bahwa industri keripik pisang layak untuk direalisasikan, karena mempunyai waktu pengembalian lebih cepat dibandingkan dengan umur proyek. Hasil penelitian Sajari et al (2017), pada industry keripik mawar diperoleh bahwa penerimaan yaitu Rp.60.750.000,00/ bulan dengan biaya produksi yang dikeluarkan sebesarRp.38.508.054,00/bulan dan diperoleh keuntungan sebesar Rp.22.241.946,00/ bulan. Hasil kelayakan usaha (R/C) Ratio yaitu perbandingan antara penerimaan dengan total biaya diperoleh nilai $(\mathrm{R} / \mathrm{C})$ Ratio 1,57 atau 1,57 > 1. (B/C).

Analisis Kepekaan/Sensitivitas. Berdasarkan analisis sensitivitas yang dilakukan terhadap kenaikan bahan baku dan bahan pembantu diperoleh usaha maksimal sebesar 15\% per tahun (Tabel 5).

Tabel 5. Perbandingan kondisi kelayakan investasi saat terjadi kenaikan bahan baku dan bahan pembantu.

\begin{tabular}{lcrrr}
\multirow{2}{*}{ Kriteria Investasi } & \multirow{2}{*}{ Standar } & \multicolumn{3}{c}{ Analisis Sensitivitas Kenaikan Harga Bahan Baku dan } \\
& & \multicolumn{3}{c}{ Bahan Pembantu } \\
\cline { 3 - 5 } & $>1$ & 30.593 .325 .147 & 22.692 .699 .994 & Naik 10\% \\
\hline NPV (Rp.) & $>12,5 \%$ & $35,78 \%$ & $25,76 \%$ & $15 \%$ \\
IRR (\%) & $>1$ & 4,26 & 3,32 & $15,82 \%$ \\
Net B/C & $>10$ & 2,35 & 3,01 & 2,42 \\
PBP (tahun) & & & & 4,14 \\
\hline
\end{tabular}

\section{KESIMPULAN}

Lokasi pabrik terpilih adalah Kecamatan Ketapang dengan nilai Metode Perbandingan Eksponensial (MPE) dengan nilai sebesar 11129. Analisis kelayakan industri keripik pisang dinyatakan layak dengan nilai NVP Rp. 38.418.770.971,- IRR 46,43 \%, nilai B/C ratio 5,27, dan pay back periode 1 tahun 11 bulan. Usaha menjadi tidak layak jika terjadi kenaikan bahan baku sebesar $15 \%$

\section{DAFTAR PUSTAKA}

[BPS]. Badan Pusat Statistik (2017) Produksi Tanaman Buah-Buahan - Pisang. https://bps.go.id/site/pilihdata.

[BPS]. Badan Pusat Statistik Lampung Selatan (2016) Statistik Daerah Kabupaten Lampung Selatan 2016. BPS Lampung Selatan, Kalianda.

Direktorat Jenderal Pengolahan dan Pemasaran hasil Pertanian. (2015) 'Pengolahan Pisang sebagai Kripik Pisang Dalam Potensi Olahan dan Prospek.', Direktorat Jenderal Pengolahan dan Pemasaran hasil Pertanian. Kementerian Pertanian.http://agribisnis.net/news/539/pengolahan-pisang-sebagai-kripikpisang-dalam-potensi-olahan-dan-prospek.Diunduh: 22 September 2015.

Apriyani. M., Saty, F.M., \& Asliana, E. (2019) 'Faktor yang mempengaruhi kaeputusan petani pisang di Lampung', in Prosiding Seminar Nasional Pengembangan Teknologi Pertanian Politeknik Negeri Lampung (hlm. 45-50). 8 Oktober 2018. Lampung:Polinela. 
Babu, M. A., Suriyakala, M. A. \& Gothandam, K. M. (2012) 'Varietal impact on phytochemical contents and antioxidant properties of musa acuminata (Banana)', Journal of Pharmaceutical Sciences and Research.

Candy, N.G \& Pamungkas. (2013). Penentuan alternative lokasi industri pengolahan sorgum di lamongan. Jurnal Teknik Pommit, 2(2): 211-214.

Chandra, S., Baravalia, Y., Kaneria, M., \& Rakholiya, K. (2010) 'Fruit and Vegetable Peels- Srong Natural Source of Antimicrobics. Current Research. Department of Biosciences, Saurashtra University, Gujarat, India. Pp. 444 - 450.

Direktorat Pengolahan Hasil Pertanian. (2009) SPO Pengolahan Pisang. Direktorat Pengolahan Hasil Pertanian. Direktorat Jenderal Pengolahan dan Pemasaran Hasil Pertanian, Jakarta.

Gray, C. (2007) Pengantar Evaluasi Proyek, PT Gramedia Pustaka Utama. Available at: https://books.google.co.id/books/about/Pengantar_Evaluasi_Proyek_Ed2.html?hl=id\&id=KlsYdLc7 EEkC\&redir_esc=y.

Harlistaria, M.F., Wignyanto, W., \& Ikasari, D. M. (2012) 'Analisis Kelayakan Teknis Dan Finansial Produksi Sosis Jamur Tiram Pada Skala Industri Kecil (Studi Kasus Di Budidaya Jamur Tiram "Wahyu" Kota Mojokerto).', Jurnal Industria, 1 (2), pp. 105-114.

Ibrahim, Y. (2009) Studi Kelayakan Bisnis. Edisi Revisi. Jakarta: Rineka Cipta.

Marimin \& Maghfiroh, N. (2011) Aplikasi Teknik Pengambilan Keputusan Dalam Manajemen Rantai Pasok. Bogor: IPB Press.

Mariyah. (2010) 'Analisis finansial budidaya ayam petelur di Kalimantan Timur', Jurnal Ekonomi Pembangunan dan Perencanaan (EPP), 7, pp. 6-13.

Maulana, Y,S. (2018). Analisis faktor yang mempengaruhi Lokasi pabrik PT Sung Chang Indonesia Cabang kota Banjar. Jurnal Ilmiah Administrasi Bisnis. 2(2): 212-221.

Nagarajaiah, S. B. \& Prakash, J. (2011) 'Chemical composition and antioxidant potential of peels from three varieties of banana. As.', J. of Food and Agroindustry, 4 (01), pp. 31-46.

Ningsih, A. P., Nurmiati \& Agustien, A. (2013) 'Uji Aktivitas Antibakteri Ekstrak Kental Tanaman Pisang Kepok Kuning ( Musa paradisiaca Linn .) terhadap Staphylococcus aureus dan Escherichia coli’, Jurnal Biologi Universitas Andalas (J.Bio UA.).

Nurainy, F., Nawansih, O. \& Sitanggang, M. M. (2017) 'Analisis Finansial dan Sensitivitas Usaha Kecil Menengah Dodol Coklat’, Jurnal Penelitian Pertanian Terapan. doi: 10.25181/jppt.v15i3.133.

Okorondu,S.I., Mepba, H.D., Okorondu, M.M.O., \& Aririatu, L. E. (2010) 'Antibacterial properties of Musa paradisiacal peel extract.', J. of Current Trends in Microbiolog, 6, pp. 21 - 26.

Octiananda, C.T \& Nazamuddin. (2016). Analisis Penentuan Lokasi: Studi Kasus Industri Rumah Tangga (Home Industry) Di Wilayah Kota Banda Aceh. Jurnal Ilmiah Mahasiswa, 1(2), pp. 438445

Padangaran, A. M. (2008) Manajemen Proyek Pertanian. Kendari: Program Pascasarjana Unhalu.

Prabawati, S., S. \& D. A. S. 2008. Teknologi Pasca panen dan Teknik Pengolahan Buah Pisang. Bogor: Bogor: Balai Besar Penelitian dan Pengembangan Pascapanen Pertanian; Balai Penelitian dan Pengembangan Pertanian. 
Sajari, I; Elfiana, \& Martina. (2017). Analisis Kelayakan Usaha Keripik Pada UD. Mawar Di Gampong Batee Ie Liek Kecamatan Samalanga Kabupaten Bireuen. Jurnal S. Pertanian 1(2), pp. 116-124.

Setiawati, I, Rochdiani, D. \& S. (2017) 'Strategi pengembangan agroindustri keripik pisang (studi kasus pada seorang pengusaha keripik pisang di desa Hegarmanah kecamatan Cidolog kabupaten Ciamis).', Jurnal Ilmiah Mahasiswa Agroinfo Galuh, 4 (2), pp. 234-243.

Sumathy, V. (2011) 'In vitro bioactivity and phytochemical screening of Musa acuminata flower', Pharmacologyonline.

Yuliana, N; Hidayati, S \& Cakradinata, R. (2019). 'Potential agroindustry of banana in lampung province. $\mathrm{T}$ ', in he 2nd International Conference On Green Agro-Industry And Bioeconomy. 18-20 September 2018, p. (hlm. 160-166). Malang. 